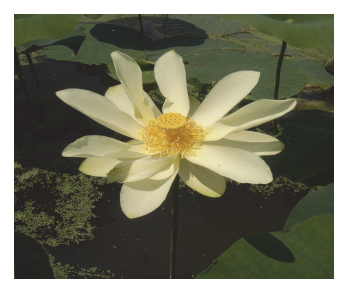

\title{
Use of Strategic Placement of Dredged Sediments to Support Horseshoe Island in the Atchafalaya River, Louisiana: A Preliminary Ecological Survey
}

\author{
By Jacob F. Berkowitz', Nathan R. Beane ${ }^{2}$, Darrell E. Evans ${ }^{1}$, \\ Burton Suedel ${ }^{3}$, and Jeffrey M. Corbino ${ }^{4}$
}

PURPOSE: This technical note describes an Engineering With Nature (EWN) project being conducted in the Atchafalaya River, LA. The current work presents a wetland classification, vegetation survey map, preliminary ecological inventory, and soil descriptions for an island receiving strategically placed dredged sediments (i.e., Horseshoe Bend Island) located within the Atchafalaya River. The practice of strategically placing dredged sediments upriver of a naturallyoccurring island was conducted with the intent of aiding the islands growth to produce greater environmental benefits than otherwise would be present using more conventional placement practices. Results provide background information regarding ecosystem classification and mapping, floral and faunal composition of the island, and background data supporting future research efforts. Opportunities for additional research are also presented.

BACKGROUND: Horseshoe Bend is a segment of the Atchafalaya River and Bayous Chene, Boeuf, and Black Federal navigation channel located in the lower Atchafalaya River approximately 20 miles south of Morgan City, LA (Figure 1). Although dredging of the navigation channel received original authorization in 1910, active maintenance dredging of Horseshoe Bend was not required until 1990 because natural channel depths exceeded authorized dimensions. Beginning in 1990 and proceeding thru 2013, 17 maintenance dredging events within this segment occurred at a return interval of 1 to 3 years, with each event resulting in the removal of between 0.5 and 2.7 million cubic yards of shoal material.

During the 1990s, placement of shoal material dredged from Horseshoe Bend occurred at eight wetland development sites located along the river's banklines adjacent to the channel. Capacity of these placement sites was nearly exhausted by 1999. Thus, to meet the anticipated disposal requirements for future channel maintenance, the US Army Corps of Engineers (USACE) New Orleans District (MVN) evaluated three placement alternatives: (1) convert the wetland development sites into upland disposal areas; (2) open water placement of dredged material via a long-distance pipeline into the open waters of the Atchafalaya Bay; and (3) mounding of material at mid-river open water placement sites within a 350-acre (142 ha) area immediately adjacent to the navigation channel and upriver of a small naturally forming island (Figure 2). Environmental and cost concerns precluded the selection of alternatives (1) and (2). The third alternative was selected on a trial basis to investigate the impacts of mid-river placement on shoaling trends downriver of the site.

\footnotetext{
${ }^{1}$ USACE, ERDC, Environmental Laboratory, Wetlands and Coastal Ecology Branch.

${ }^{2}$ USACE, ERDC, Environmental Laboratory, Ecological Resources Branch.

${ }^{3}$ USACE, ERDC, Environmental Laboratory, Environmental Risk Assessment Branch.

${ }^{4}$ USACE, New Orleans District (MVN).
}

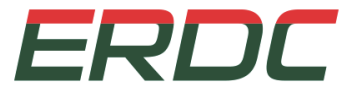

Engineer Research and Development Center 


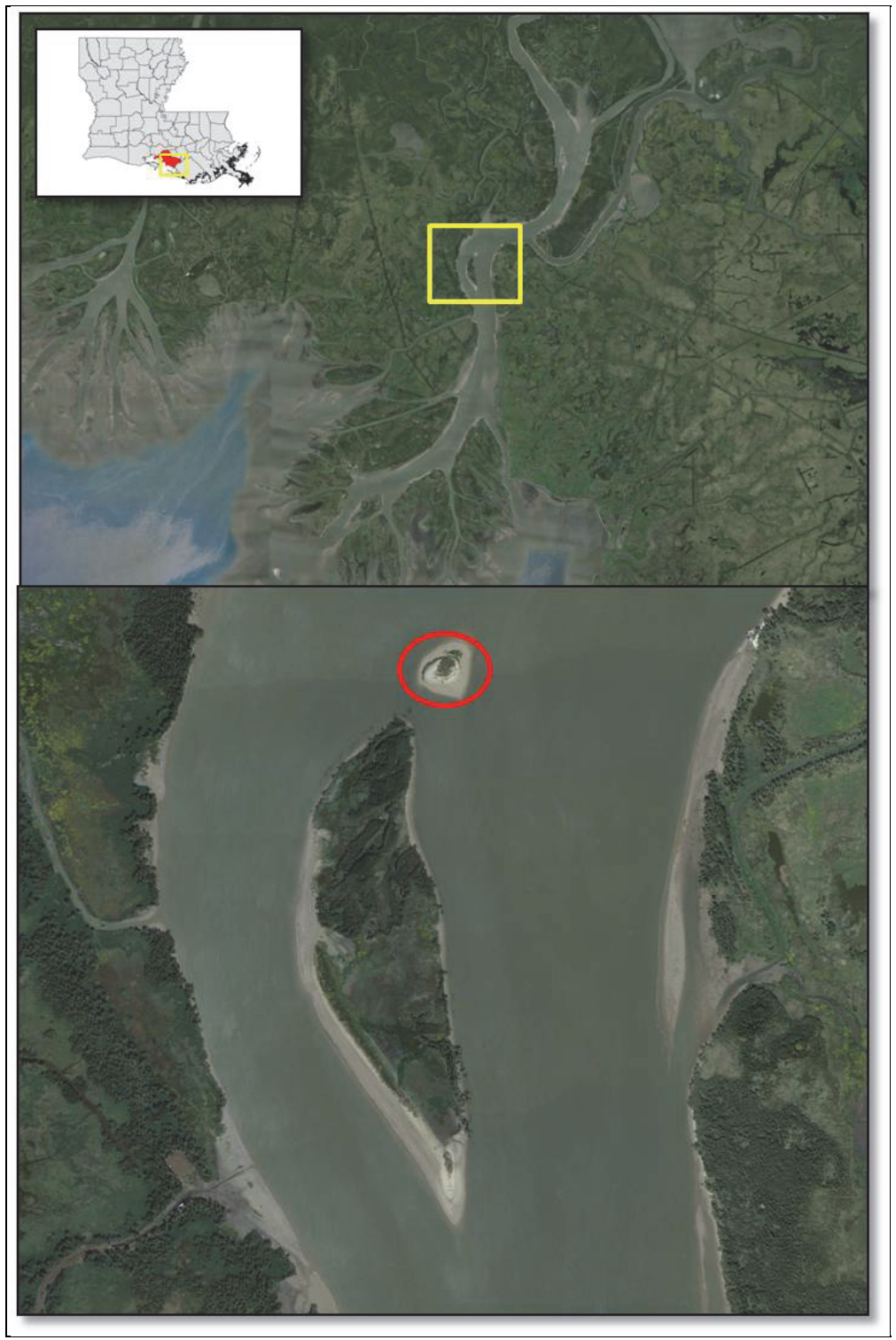

Figure 1. Study location at Horseshoe Bend Island within the Atchafalaya River, St. Mary Parish, LA (rectangle in upper photo), and a closer view of the approximately 35 ha island supported by strategic dredge material placement (lower photo). Note the small dredged material mound placed immediately upriver (north) of the island (circle).

Beginning in 2002, placement of the sediment dredged from Horseshoe Bend occurred at the mid-river open water placement area. Placement of between 0.5 to 1.8 million cubic yards of sediment was conducted every 1 to 3 years which influenced and contributed to the development of an approximately $35 \mathrm{ha}$ ) mid-river island (Figures 1 and 2).

This beneficial use of dredged material is consistent with Engineering With Nature, a USACE initiative enabling more sustainable delivery of economic, social and environmental benefits associated with water resources infrastructure (http://el.erdc.usace.army.mil/ewn/). Specific 

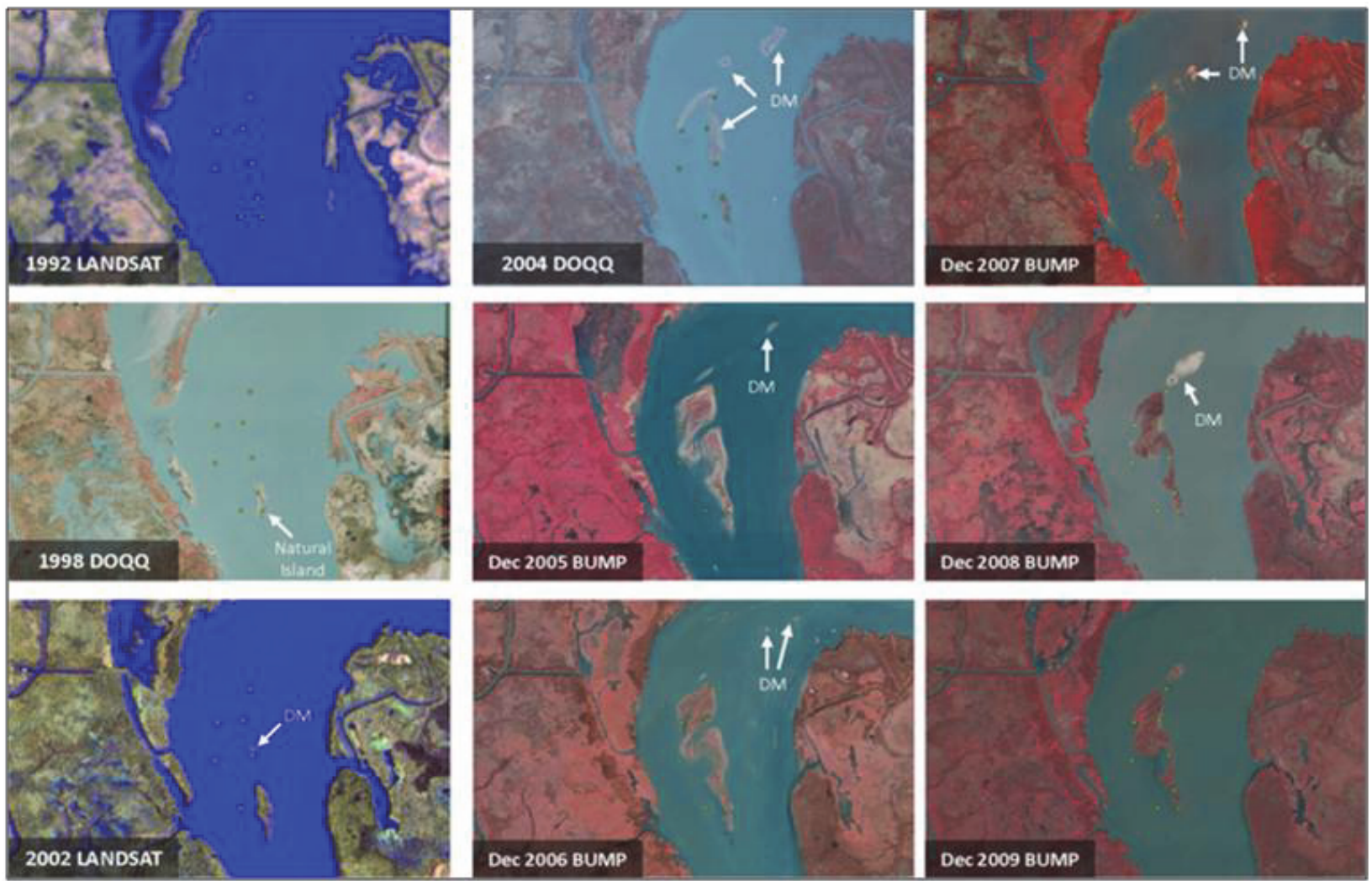

Figure 2. Imagery displaying island location prior to dredged material (DM) placement and subsequent formation (1992 and 1998 images), establishment, and growth since dredged material placement began in 2002 (imagery provided by USACE MVN).

Engineering with Nature concepts addressed through the project include 1) the use of science and engineering to produce operational efficiencies supporting sustainable delivery of project benefits, and 2) the use natural processes to maximum benefit, thereby reducing demands on limited resources, minimizing the environmental footprint of projects, and enhancing the quality of project benefits. An added benefit being realized is that as the island has enlarged it began to reduce the overall cross sectional area of the river, increasing flow through the navigation channel to velocities that were sufficient to reduce shoaling and maintenance dredging requirements.

METHODS: Various methods were employed to conduct an initial ecological survey of the island. Surveys were conducted to determine the types of wetlands present, quantify major vegetative communities, develop a vegetation community map of the island, conduct observational faunal surveys, and determine soil physical-chemical characteristics. Site visits occurred August 27 and 28, 2013. River stage reported at the Morgan City gauge (river mile 117.7; longitude 91.21083333, latitude 29.69638889) was $+2.18 \mathrm{NV} 88$ on the $27^{\text {th }}$ and $+2.21 \mathrm{ft}$ on the $28^{\text {th }}$ (USACE 2013).

Ecosystem classification and mapping. The "Classification of wetlands and deepwater habitats of the United States" (Cowardin et al. 1979) formed the basis of the classification scheme utilized. Aerial image interpretation, ground truthing, and GPS reference points supported the determination of ecological community boundaries and island area. 
Floral Community. Vegetation sampling included quantification of dominant species within each distinct vegetative community. We established 14 sample plots on the island during our initial site visit. Plot selection examined representative areas within each of the ecosystem classes identified on the island, a randomized sampling design remains beyond the scope of the preliminary investigation. Seven plots were set up within forested and shrub-scrub environments of the island and seven additional plots were evaluated in aquatic bed environments with submerged and emergent vegetation (Figure 3). Several variables were measured within each wooded area sampled including: 1) the identification of dominant overstory species, 2) stem counts of overstory tree and shrub species within 0.04 ha plots, and 3) measurements of stem density of the shrubsapling strata (i.e., woody stems $<10 \mathrm{~cm}$ diameter at breast height (dbh) and $>1.2 \mathrm{~m}$ tall). The last of these occurred within two nested, 0.004 ha sub-plots located within each sample plot. Estimates of herbaceous and woody vegetation ground cover $\leq 1.4 \mathrm{~m}$ were also made within four representative $1 \mathrm{~m}^{2}$ sub-plots in each sample plot. A comprehensive list of all plants observed on the island was developed. Plants were identified to species or lowest taxonomic level, with nomenclature following USDA PLANTS Database (USDA 2013).

In the aquatic bed vegetation areas, variables measured at sample plots included an ocular estimation of percent cover (USACE 2010) of herbaceous and woody vegetation as well as estimates of percent cover of any free-floating or visibly submerged aquatic species. Additionally, all plants observed within floating bed environments on the island were identified or collected for further identification in the lab. All specimens were identified to species, when possible, to provide a comprehensive baseline survey of all observed herbaceous and woody flora.

Faunal Community. An in-depth survey/census of the island's faunal species remains beyond the scope of the initial survey. However, incidental observations of all faunal species observed on the island during the site visit were made and recorded. Species were identified visually, by their calls, or by the presence of indirect signs (i.e., scat, tracks, etc.).

Soils. Basic wetland soil descriptions were made at each sample location within forested and scrub-shrub wetland communities (USACE 2010; USDA-NRCS 2011). Soil descriptions included the determination of soil horizonation, matrix color, redoximorphic features, and textural analysis. Soil descriptions focused on near surface $50 \mathrm{~cm}$ (20 in) horizons. Additionally, soil sample collections utilized $98 \mathrm{~cm}^{3}\left(6.3 \mathrm{in}^{3}\right)$ soil cores to determine volumetric water content and bulk density. The installation of replicate feldspar marker horizons followed methods developed by Cahoon and Turner (1989). The feldspar horizons deployed occupy $1 \mathrm{~m}^{2}$ quadrats, allowing for a determination of sedimentation rates and soil horizonation during future surveys of the island (USGS 2010). Additionally, one automated groundwater table monitor was deployed along the natural levee located on the southeast side of the island. The automated datalogger records water table levels within the upper 12 inches $(30 \mathrm{~cm})$ of the surface twice daily (USACE, 2005).

\section{RESULTS:}

Ecosystem Classification. The results of the ecosystem classification effort revealed four distinct ecological communities occurring within the study area (Figure 3). A brief generic description of each community is presented below consistent with the classification system developed by Cowardin et al. (1979). 


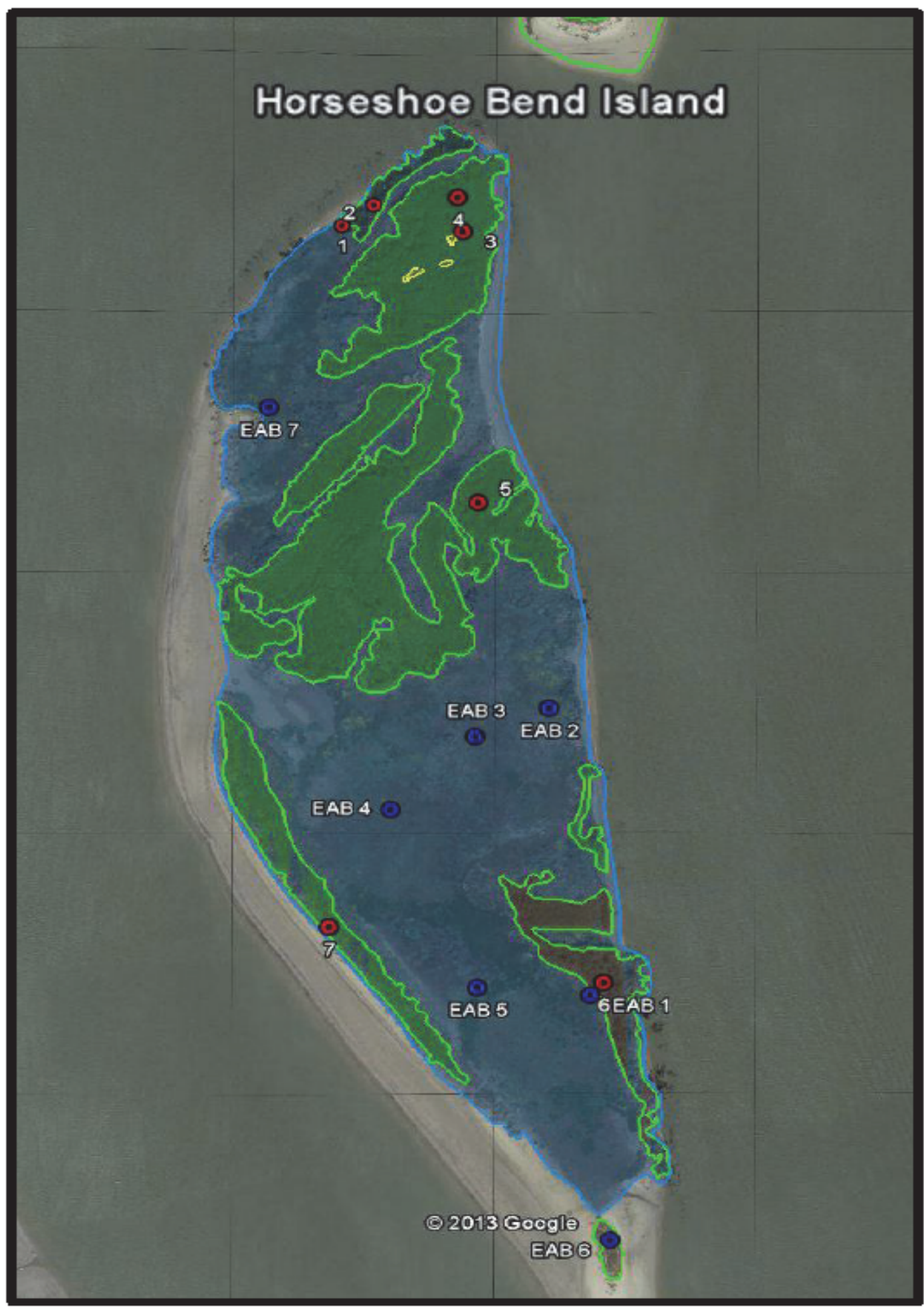

Figure 3. Horseshoe Bend Island delineation of young wooded (green), mature wooded forested and scrub-shrub wetlands (brown), along with aquatic bed community types (blue). Emergent transitional areas occur within the boundaries between wooded and aquatic bed features. Also shown are sample plot locations (1 7) and observation points within aquatic bed habitats (EAB 1-7). A dredged material feeder mound is seen at the top right of the figure. 
Palustrine Broadleaf Forested Wetland - consists of temporarily flooded zones exhibiting established woody vegetation with an overstory approximately $>6.1 \mathrm{~m}(20 \mathrm{ft})$ in height. These wetlands receive intermittent exposure to freshwater inputs $(<0.05 \%$ salinity $)$ from groundwater saturation, overbank, and backwater flooding regimes. The frequency and duration of flooding varies on both local and regional scales. Common dominants include species such as ashes (Fraxinus pennsylvanica and F. nigra), black gum (Nyssa sylvatica), tupelo gum ( $N$. aquatica), swamp white oak (Quercus bicolor), overcup oak (Q. lyrata), and willow (Salix spp.). Wetlands in this subclass generally occur on mineral soils or highly decomposed organic soils. Palustrine broadleaf forested wetlands occur within the most stable, established, and highest elevation portions of the island; representing the most mature and structurally complex community type observed.

Palustrine Broadleaf Scrub-Shrub Wetland - consists of temporarily flooded zones exhibiting established woody vegetation $<6.1 \mathrm{~m}$ in height. These wetlands receive intermittent exposure to freshwater inputs $(<0.05 \%$ salinity) from groundwater saturation, overbank, and backwater flooding regimes. The frequency and duration of flooding varies on both local and regional scales. The species include true shrubs, young trees, and trees or shrubs that are small or stunted because of environmental conditions. Scrub-Shrub Wetlands may represent a successional stage leading to Forested Wetland, or they may be relatively stable communities. They represent one of the most widespread classes in the United States. Dominance types include sea-myrtle (Baccharis halimifolia), marsh elder (Iva spp.), alders (Alnus spp.), willows (Salix spp.), buttonbush (Cephalanthus occidentalis), red osier dogwood (Cornus stolonifera), honeycup (Zenobia pulverulenta), spirea (Spiraea douglasii), bog birch (Betula pumila), and young trees of species such as red maple (Acer rubrum) or black spruce (Picea mariana). Wetlands in this subclass generally occur on mineral soils or highly decomposed organic soils. Palustrine broadleaf scrubshrub wetlands occur within less stable, geomorphically younger, and moderate elevation portions of the island; representing the second-most mature and structurally complex ecosystem type observed.

Palustrine Persistent Emergent Wetland - consists of seasonally flooded herbaceous areas characterized by erect, rooted, herbaceous hydrophytes, excluding mosses and lichens. This vegetation is present for most of the growing season in most years. These wetlands usually remain dominated by perennial plants. Palustrine Persistent Emergent Wetlands contain a vast array of grasslike plants such as cattails (Typha spp.), bulrushes (Scirpus spp.), saw grass (Cladium jamaicense), sedges (Carex sp.); and true grasses such as reed (Phragmites australis), manna grasses (Glyceria spp.), slough grass (Beckmannia syzigachne), and whitetop (Scolochloa festucacea). There is also a variety of broadleaved persistent emergents such as purple loosestrife (Lythrum salicaria), dock (Rumex mexicanus), waterwillow (Decodon verticillatus), and many species of smartweeds (Polygonum sp.). Palustrine persistent emergent wetlands occur within the transition zones between forest/scrub-shrub wetlands and aquatic bed features. Emergent dominated ecosystems represent dynamic ecosystems with homogenous vegetative structure.

Palustrine Aquatic Bed Wetland - consists of wetlands and deepwater habitats dominated by plants that grow principally on or below the surface of the water for most of the growing season in most years. Water regimes include irregularly exposed, regularly flooded, permanently flooded, intermittently exposed, semipermanently flooded, and seasonally flooded. Aquatic Beds represent a diverse group of plant communities that require surface water for optimum growth 
and reproduction. They are best developed in relatively permanent water or under conditions of repeated flooding. The plants are either attached to the substrate or float freely in the water above the bottom. Rooted vascular aquatic plants occur at all depths within the photic zone. They often occur in sheltered areas where there is little water movement. Typical inland genera include pondweeds, horned pondweed (Zannichellia palustris), ditch grasses (Ruppia sp.), wild celery (Apium graveolens), and waterweed (Elodea spp.). Some of the rooted vascular species are characterized by floating leaves. Typical dominants include water lilies (Nymphaea spp.; Nuphar spp.), floating-leafpondweed (Potamogeton natans), and water shield (Brasenia schreberi). Plants such as yellow water lily (Nuphar luteum) and water smartweed (Polygonum amphibium), which may stand erect above the water surface or substrate, may be considered either emergent or rooted vascular aquatic plants, depending on the life form adopted at a particular site. Beds of floating vascular plants occur mainly in the Palustrine system. The plants float freely either in the water or on its surface. Dominant plants that float on the surface include duckweeds (Lemna sp.; Spirodela sp.), water lettuce (Pistia stratiotes), and water hyacinth (Eichhornia crassipes). Palustrine aquatic bed wetlands occur at the lowest island elevations.

Floral Community. Seven plots were measured on well-established portions of the island (Figure 3, points 1-7) which were dominated by woody vegetation and classified as Palustrine Broadleaf Forested Wetlands in older more established areas as well as Palustrine Scrub-Shrub Wetlands in early successional areas (Cowardin et al., 1979). The temporarily flooded forested areas exhibited clear distinguishing characteristics compared with seasonally and semipermanently flooded plots based on the dominance of woody vegetation. Forested zones occupied approximately 12 ha of the island (Figure 3). Specifically, the majority of the forested areas displayed younger stand ages representing 10.5 ha, while the older portions of the forest represented approximately 1.3 ha. Both of these temporarily flooded forest habits remained disproportionately dominated by black willow (Salix nigra), with eastern baccharis (Baccharis halimifolia) and common elderberry (Sambucus nigra ssp. canadensis) frequently observed as codominants within forested stands. Other infrequently observed codominants included annual marsh elder (Iva annua) and red mulberry (Morus rubra). The average diameter of woody stems within well-established portions of the island was $12.5 \mathrm{~cm}$ dbh, ranging from $5-20 \mathrm{~cm}$ dbh. Total tree density per hectare ranged from 1,500 to 17,325 woody stems, resulting in varying amounts of ground cover across all forested sites (Table 1). Average tree height was $6 \mathrm{~m}$ across all plots measured, with a maximum height of approximately $10 \mathrm{~m}$.

The herbaceous layer was diverse both within and among the younger- and older-aged stands, with clear distinctions of understory conditions by age class not readily observed. However, across both stand types, consistent patterns of understory cover varied from densely aggregated clumps of vegetation $>1 \mathrm{~m}$ in height (e.g., coco yam (Colocasia escuelenta)), to extensive ground cover of invasive torpedo grass (Panicum repens), smartweed (Polygonum spp.), or invasive alligatorweed (Alternantherea pholoxeroides). On the highest elevational areas, a pronounced abundance of dogfennel (Eupatorium capillifolium) was observed, with a distinct absence of coco yam. Additionally, stiff dogwood (Cornus foemina) was found only in the higher elevation areas located on the southeast portion of the island. Additionally, black willow and common elderberry sprouts as well as peppervine (Ampelopsis arborea) were frequently encountered. Less commonly observed, but scattered throughout both stand types, were buttonbush (Cephalanthus occidentalis), climbing hempvine (Mikania scandens), whorled marsh pennywort (Hydrocotyle verticillata), smallspike false nettle (Boehmeria cylindrica), flatsedge (Cyperus sp.), goldenrod (Solidago sp.), 
hairypod cowpea (Vigna luteola), broadleaf cattail (Typha latifolia), invasive Chinese tallowtree (Triadica sebifera), rosemallow (Hibiscus lasiocarpos), and broadleaf arrowhead (Sagittaria latifolia). The unvegetated areas of the ground throughout forested areas exhibited small-sized downed dead wood placed during flooding on the island.

Table 1. Vegetation summary for wooded areas of Horseshoe Bend Island, Atchafalaya River, Aug 2013. Data include the number of trees within each sample plot, dominant tree species, tree density, scrub-sapling stems within each sample plot, shrub-sapling density, ground vegetation within each sample plot, and percent ground cover. SANI ${ }^{*}=$ Black willow (Salix nigra).

\begin{tabular}{|c|c|c|c|c|c|c|c|c|c|c|c|}
\hline \multirow[b]{3}{*}{ Site } & \multirow{3}{*}{$\begin{array}{l}\text { Tree stem } \\
\text { count }\end{array}$} & \multirow{3}{*}{$\begin{array}{l}\text { Dominant } \\
\text { species }\end{array}$} & \multirow{3}{*}{$\begin{array}{l}\text { Density } \\
\text { (stems/ha) }\end{array}$} & \multirow{2}{*}{\multicolumn{2}{|c|}{\begin{tabular}{||c|}
$\begin{array}{c}\text { Scrub-sapling } \\
\text { density } \\
\text { (count) }\end{array}$ \\
Plot \\
\end{tabular}}} & \multirow{3}{*}{$\begin{array}{l}\text { Stem } \\
\text { Density } \\
\text { (Stems/ac) }\end{array}$} & \multirow{2}{*}{\multicolumn{4}{|c|}{$\begin{array}{c}\text { Ground vegetation } \\
\text { cover }(\%)\end{array}$}} & \multirow{3}{*}{$\begin{array}{l}\text { Ground } \\
\text { cover } \\
(\%)\end{array}$} \\
\hline & & & & & & & & & & & \\
\hline & & & & 1 & 2 & & 1 & 2 & 3 & 4 & \\
\hline 1 & 287 & SANI $^{*}$ & 7175 & 0 & 1 & 125 & 35 & 20 & 30 & 40 & 31.3 \\
\hline 2 & 225 & SANI & 5625 & 0 & 0 & 0 & 25 & 30 & 10 & 15 & 20 \\
\hline 3 & 693 & SANI & 17325 & 0 & 0 & 0 & 30 & 65 & 60 & 40 & 48.8 \\
\hline 4 & 472 & SANI & 11800 & 0 & 0 & 0 & 0 & 0 & 10 & 10 & 5 \\
\hline 5 & 370 & SANI & 9250 & 0 & 0 & 0 & 0 & 0 & 25 & 40 & 16.3 \\
\hline 6 & 60 & SANI & 1500 & 4 & 2 & 750 & 0 & 5 & 0 & 10 & 3.8 \\
\hline 7 & 298 & SANI & 7450 & 0 & 0 & 0 & 35 & 5 & 10 & 5 & 13.8 \\
\hline
\end{tabular}

\begin{tabular}{|l||l|l||}
\hline \multicolumn{3}{|l||}{ Table 2. Percent cover estimates for floating and submerged vegetation on } \\
Horseshoe Bend Island. Note: Open water included in percent cover estimates. \\
\hline \hline Species & Common name & Average cover (\%) \\
\hline \hline Eichhornia crassipes & common water hyacinth & 37.5 \\
\hline Alternantherea philoxeroides & alligatorweed & 34.8 \\
\hline Salvinia minima & water spangles & 31.7 \\
\hline Lemna minor & common duckweed & 12.5 \\
\hline Ludwigia sp. & primrose-willow & 10.0 \\
\hline Hydrilla verticillata & waterthyme & 6.5 \\
\hline Nelumbo lutea & American lotus & 4.6 \\
\hline Open water & Open water & 5.2 \\
\hline Leersia oryzoides & rice cutgrass & 1.0 \\
\hline Colocasia esculenta & coco yam & 0.2 \\
\hline \hline
\end{tabular}

Within the aquatic bed environments, six plots with four $1 \mathrm{~m}^{2}$ subplots located at each sample point supported the identification and quantification of vegetation assemblages and open water areas. At the time of the survey, aquatic bed features occupied a large portion of the island's vegetation, representing approximately 23.1 ha $(66 \%)$ of the 35 ha island. Within each subplot, ocular percent cover estimates of vegetation were recorded for each species observed. All subplots were averaged, 
with estimates greater than $100 \%$ cover possible due to vertical stratification of plant material above and below the water surface. The characteristically dominant species included common water hyacinth (Eichhornia crassipes (Mart.) Solms), alligatorweed (Alternantherea philoxeroides (Mart.) Griseb.), water spangles (Salvinia minima Baker), common duckweed (Lemna minor L.), and primrose-willow (Ludwigia sp.) (Table 2). Several invasive species were observed during the survey (Appendix A).

Faunal Community. Examination of the island's faunal communities included recording all species observed during fieldwork. Twenty-three species representing 12 Families were observed on the island during the site visit (Table 3 ). Avian wading species comprised the primary vertebrate inhabitants observed on the island with six species of wading birds encountered. This included great blue herons, Louisiana herons, great white herons, reddish egrets, little blue herons, and white ibises. An active white ibis rookery was observed on the northwest corner of the island. Several species of waterbirds (i.e., gulls and terns) were observed in the immediate vicinity of the island but only five (5) species (Caspian tern, common tern, gull billed terns, Forester's tern, and Franklin's gull) were observed on the site (primarily on the small, sandy island that lies north of the main island). No neotropical migrant observations occurred during fieldwork. Four (4) reptile species were observed and the exoskeleton of one dead White River crawfish (Procambarus acutus) was found during the ecological surveys. No mammals were visually observed on the island but several burrows and "runs" (likely to be made by small mammals) were noted at various locations. One bald eagle (Haliaeetus leucocephalus) was seen taking flight from the island on the second morning of fieldwork, but no other species of special concern were observed.

Soils. The soils examined throughout the island consisted of textures ranging from loamy sands to very fine sands. In general, the surface soil layers contained thin dark, organic rich horizons (10YR $3 / 1$ or 10 YR 3/2) underlain by depleted materials (e.g., 10YR 5/2) in subsurface horizons. Soil horizons also exhibited redoximorphic iron and manganese concentrations in the form of rust colored (e.g., 10 YR5/4) pore linings and masses within the soil matrix. The presence of dark soil layers near the surface indicates the accumulation of carbon and organic materials due to frequent inundation and saturation and associated retardation of microbial decomposition rates. Additionally, the presence of depleted materials and redoximorphic features at depth indicates that biogeochemical reduction is occurring, an important function of hydric soils. All soils examined met one or more field indicators of hydric soils (USDA-NRCS 2011). Additionally, soils displayed the presence of buried surface horizons, signatures of recent sediment inputs, and indicators of active soil forming processes associated with overbank flooding and material deposition. Complete soil descriptions are provided in Table 4. Observed indicators included: F3 - depleted matrix, S6 sandy redox, and A5 - stratified layers. 


\section{Table 3. Alphabetical list of faunal species observed on Horseshoe Bend Island,} 27-28 August 2013.

\begin{tabular}{|c|c|c|c|}
\hline Scientific Name & Common Name & Family & Regulatory Status \\
\hline $\begin{array}{l}\text { Haliaeetus } \\
\text { leucocephalus }\end{array}$ & Bald eagle & ACCIPITRIDAE & $\begin{array}{l}\text { Delisted due to Recovery - removed in } \\
2007\end{array}$ \\
\hline $\begin{array}{l}\text { Alligator } \\
\text { mississippiensis }\end{array}$ & $\begin{array}{l}\text { American } \\
\text { alligator }\end{array}$ & ALLIGATORIDAE & $\begin{array}{l}\text { Afforded "threatened" status by federal } \\
\text { government but state-approved } \\
\text { management and control programs } \\
\text { exist in several states }\end{array}$ \\
\hline Anas discors & Blue-winged teal & ANATIDAE & Not Listed \\
\hline Ardea alba & Great white heron & ARDEIDAE & Not Listed \\
\hline Ardea herodias & Great blue heron & ARDEIDAE & Not Listed \\
\hline Egretta caerulea & Little blue heron & ARDEIDAE & Not Listed \\
\hline Egretta rufescens & Reddish egret & ARDEIDAE & Not Listed \\
\hline Egretta thula & Snowy egret & ARDEIDAE & Not Listed \\
\hline Egretta tricolor & Louisiana heron & ARDEIDAE & Not Listed \\
\hline Procambarus acutus & $\begin{array}{l}\text { White River } \\
\text { crawfish }\end{array}$ & CAMBARIDAE & Not Listed \\
\hline Nerodia rhombifer & $\begin{array}{l}\text { Diamond-backed } \\
\text { watersnake }\end{array}$ & COLUBRIDAE & Not Listed (non idigenous) \\
\hline $\begin{array}{l}\text { Thamnophis proximus } \\
\text { orarius }\end{array}$ & $\begin{array}{l}\text { Gulf Coast ribbon } \\
\text { snake }\end{array}$ & COLUBRIDAE & Not Listed \\
\hline $\begin{array}{l}\text { Corvus } \\
\text { brachyrhynchos }\end{array}$ & American crow & CORVIDAE & Not Listed \\
\hline Anolis carolinensis & Carolina anole & DACTYLOIDAE & Not Listed \\
\hline Quiscalus quiscula & Common grackle & ICTERIDAE & Not Listed \\
\hline Gelochelidon nilotica & Gull billed tern & LARIDAE & Not Listed \\
\hline Hydroprogne caspia & Caspian tern & LARIDAE & Not Listed \\
\hline $\begin{array}{l}\text { Leucophaeus } \\
\text { pipixcan }\end{array}$ & Franklin's gull & LARIDAE & Not Listed \\
\hline Sterna forsteri & Forster's tern & LARIDAE & Not Listed \\
\hline Sterna hirundo & Common tern & LARIDAE & Not Listed \\
\hline $\begin{array}{l}\text { Erythemis } \\
\text { simplicicollus }\end{array}$ & $\begin{array}{l}\text { Eastern } \\
\text { pondhawk }\end{array}$ & LIBELLULIDAE & Not applicable \\
\hline Libellula needhami & $\begin{array}{l}\text { Needham's } \\
\text { skimmer }\end{array}$ & LIBELLULIDAE & Not applicable \\
\hline Fulica americana & American coot & RALLIDAE & Not Listed \\
\hline Eudocimus albus & White ibis & THRESKIORNITHIDAE & Not Listed \\
\hline Platalea ajaja & Roseate spoonbill & THRESKIORNITHIDAE & Not Listed \\
\hline Archilochus colubris & $\begin{array}{l}\text { Ruby-throated } \\
\text { hummingbird }\end{array}$ & TROCHILIDAE & Not Listed \\
\hline
\end{tabular}




\section{Table 4. Shallow soil descriptions indicating horizon depth (inches), matrix color, redoximorphic features, and soil texture at each sample plot (Plot 1- 7; Figure 3). C=redoximorphic concentration; $D=$ redoximorphic depletion;

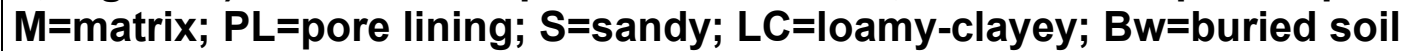 horizon; $\mathrm{OC}=$ organic matter.}

\begin{tabular}{|c|c|c|c|}
\hline Plot1 & Plot 2 & Plot 3 & Plot 4 \\
\hline $\begin{array}{l}0-12 ; 10 Y R \text { 5/2; } 20 \% \\
7.5 Y R 5 / 4 \text { C/M/PL/LC }\end{array}$ & $\begin{array}{l}\text { 0-8; } 10 \text { YR 5/2; } 20 \% \\
\text { 7.5YR 5/4 CM/PL/LC }\end{array}$ & $\begin{array}{l}\text { 0-6; 10YR 5/3; } 10 \% \\
\text { 10YR 5/6 C/PL/LC }\end{array}$ & 0-1; 10YR 3/1; high OC \\
\hline \multirow[t]{2}{*}{$\begin{array}{l}\text { 12-18; } 10 \text { YR 4/1; } 7 \% \\
\text { 7.5YR 5/4 C/M/PL/S }\end{array}$} & $\begin{array}{l}\text { 8-14; } 10 \text { YR 4/1; } 2 \% \\
\text { 7.5YR 5/4 CM/PL/LC }\end{array}$ & $\begin{array}{l}\text { 6-13; 10YR 5/1; } 20 \% \\
\text { 7.5YR 5/6 C/PL/LC }\end{array}$ & $\begin{array}{l}\text { 1-11.5 10YR 4/4; 7\% } \\
\text { 10YR 5/6 CM/LC }\end{array}$ \\
\hline & & $\begin{array}{l}\text { 13-17; } 10 \text { YR 4/1; } 10 \% \\
\text { 7.5YR 5/4 CM/S }\end{array}$ & $\begin{array}{l}\text { 11.5-16; 10YR 5/3; 7\% } \\
\text { 10YR4/6 CM; 15\% 10YR } \\
\text { 5/2 DM/LC }\end{array}$ \\
\hline Plot 5 & Plot 6 & Plot 7 & \\
\hline $\begin{array}{l}0-0.5 ; 10 Y R \text { 5/2; } 20 \% \\
\text { 10YR5/6 C/M/PL/LC }\end{array}$ & $0-0.5 ; 10$ YR $3 / 2$; high OC & $0-0.5 ; 10 Y R 2 / 1 ;$ high OC & \\
\hline $\begin{array}{l}0.5-5 \text { 10YR 4/2; 5\% } \\
10 Y R \text { 5/6 C/M/PL/Bw/LC }\end{array}$ & $\begin{array}{l}\text { 0.5-4; 10YR 5/2; } 10 \% \\
\text { 10YR 5/6 C/PL/LC }\end{array}$ & $\begin{array}{l}\text { 05.-6; } 10 Y R \text { 4/2; } 20 \% \\
\text { 10YR 5/4 C/PL/M/LC }\end{array}$ & \\
\hline \multirow[t]{2}{*}{$\begin{array}{l}5-17 ; 10 Y R \text { 5/1; } 10 \% \\
\text { 10YR 4/6 C/M/PL/LC }\end{array}$} & $\begin{array}{l}\text { 4-6.5; } 10 \text { YR 3/1; 25\% } \\
\text { 10YR 5/6 C/M/PL/Bw/LC }\end{array}$ & $\begin{array}{l}\text { 6-12 10YR 5/1; 5\% 10YR } \\
\text { 5/6 C/M/LC }\end{array}$ & \\
\hline & $\begin{array}{l}\text { 6.5-16; } 2.5 Y \text { 5/1; } 15 \% \\
\text { 10YR 4/6 C/PL/S }\end{array}$ & $\begin{array}{l}\text { 12-16; 10YR 5/3; } 10 \% \\
\text { 10YR 5/6 C/M/LC }\end{array}$ & \\
\hline
\end{tabular}

DISCUSSION: Horseshoe Bend Island exhibits four distinct wetland ecosystem classifications including forested, scrub-shrub, emergent, and aquatic bed assemblages. The prevalence of multiple ecosystem types within a relatively small area (35 ha) allows for the development of a variety of faunal and floral habitat types.

As a result, the Horseshoe Bend island displays a diverse array of species capable of providing support to the larger Atchafalaya River wetland ecosystem, with 81 plant and 23 animal species observed. For contextual purposes, Faulkner and Poach (1996) assessed the functional capacity of created and natural wetlands within the Atchafalaya Delta and determined the functional capacity within each wetland type. Faulkner and Poach conducted a vegetation survey within created and natural wetlands, identifying a total of 53 plant species; compared to more than 80 found in the current evaluation of Horseshoe Bend Island. Approximately $60 \%$ of the species reported by Faulkner and Poach listed occurred on Horseshoe Bend Island. These findings suggest that the species richness and diversity observed at Horseshoe Bend Island remains comparable, if not surpasses the values reported for other ecosystem studies conducted in the region.

Additionally, Faulkner and Poach (1996) reported that created wetlands require 5 to 10 years prior to approaching the characteristics observed within natural wetland ecosystems. Thus, the successional development of Horseshoed Bend Island appears comparable with natural wetland ecosystems based on the deposition periods of dredged materials and resulting island geomorphic features and accretion rates. 
The soils observed within the created island display common characteristics associated with riverine wetlands exposed to periodic inundation, overbank flooding, and sediment deposition. Soil profiles indicate an abundance of depleted materials interspersed with higher chroma sandy minerals from recent flooding events. Notably, buried soil horizons and wavy/turbulent boundary transitions demonstrate the frequency of deposition events as observed through the presence of stratified layers (USDA-NRCS 2011). Further, the development of dark, organic rich surface horizons indicates a decrease in microbial decomposition rates due to periodic saturation or inundation. The profusion of redoximorphic features within subsurface layers demonstrates that soil biogeochemical reduction regularly occurs within island soils. The onset of reduced, anaerobic conditions promotes wetland biogeochemical functions including carbon sequestration, nutrient cycling, removal and sequestration of elements and compounds, and denitrification (Reddy and DeLaune 2008; Smith and Klimas 2002).

Based on the initial survey of vegetation, fauna, and soils, Horseshoe Bend Island exhibits the capacity to provide ecological functions and services at levels comparable to similar-aged ecosystems within the region.

SUMMARY: The intentional placement and beneficial use of dredged material within open water areas on the Atchafalaya River supported the formation of a 35 ha island at Horseshoe Bend. Evaluation of ecosystem characteristics identified over 80 species of plants ( $85 \%$ native) and over 20 faunal species existing within four distinct habitat types (forested wetland, scrub-shrub wetland, emergent wetland, and aquatic bed wetland). Soils exhibited common characteristics associated with island formation as well as depleted matrices and redoximorphic features indicating biogeochemical processing. Future research efforts should focus on comparative investigations of reference landscapes in the region, surveys of avian usage and habitat quality, determinations of biogeochemical functions and benefits, species management for habitat improvement, colonization research, and to determine the hydrodynamic characteristics of the river in the Horseshoe Bend area. Future investigations will focus on quantifying both environmental and economic benefits of beneficially and strategically placing dredged materials to support such riverine islands providing a more complete understanding of the formation of the island so this concept can be integrated into other dredging projects in southern Louisiana and elsewhere, thereby providing substantial environmental and other benefits as part of ongoing USACE dredging activities.

POINTS OF CONTACT: For additional information, contact Dr. Jacob Berkowitz (601-6345218, Jacob.F.Berkowitz@usace.army.mil), Dr. Burton Suedel (601-634-4578, Burton.Suedel@, usace.army.mil), or Jeff Corbino (504-862-1958, Jeffery.M.Corbino@usace.army.mil). This technical note should be cited as follows:

Berkowitz, J. F., N. R. Beane, D. E. Evans, B. C. Suedel, and J. M. Corbino. 2014. Preliminary Use of strategic placement of dredged sediment to support Horseshoe Island IN THE Atchafalaya River, Louisiana: A preliminary ecological survey. DOER Technical Notes Collection ERDC TN-EWN-14-4. Vicksburg, MS: US Army, Engineer Research and Development Center. http://el.erdc.usace.army.mil/.

ACKNOWLEDGEMENTS: Thanks to Brandon Gaspard for help with field data collection and plant identification as well as the USACE New Orleans District for logistical support throughout the project. 


\section{REFERENCES}

Cahoon, D. R., and R. E. Turner. 1989. Accretion and canal impacts in a rapidly subsiding wetland. II. Feldspar marker horizon technique. Estuaries 12:260-68.

Corwardin, L. M., V. Carter, F. C. Golet, and E. T. Laroe. 1979. Reprinted 1992. Classification of Wetlands and Deepwater Habitats of the United States. Washington, D.C.: U.S. Fish and Wildlife Service, FWS/OBS-79/31.

Mitsch, W. J., L. Zhang, C. J. Anderson, A. E. Altor, M. E. Hernandez. 2005. Creating riverine wetlands: ecological succession, nutrient retention, and pulsing effects. Ecological Engineering 25, 510e527.

Post, W. 1990. Nest Survival in a Large Ibis-Heron Colony During a Three-year Decline to Extinction. Colonial Waterbirds 13(1): 50-61.

Reddy, K. R., and R. D. DeLaune. 2008. Biogeochemistry of wetlands: Science and applications. Boca Raton, FL: CRC Press.

Reinecke, K. J., R. M. Kaminski, D. J. Moorehead, J. D. Hodges and J. R. Nassar. 1989. Mississippi Alluvial Valley. Pages 203-247 in L. M. Smith, R. L. Pederson, and R. M. Kaminski, editors. Habitat management for migrating and wintering waterfowl in North America. Texas Tech University, Lubbock.

Smith, R. D., and C. V. Klimas. 2002. A Regional Guidebook for Applying the Hydrogeomorphic Approach to Assessing Wetland Functions of Selected Regional Wetland Subclasses, Yazoo Basin, Lower Mississippi River Alluvial Valley. ERDC/EL TR-02-4. Vicksburg, MS: U.S. Army Engineer Research and Development Center.

Song, K., S. Lee, W. J. Mitsch, and H. Kang. 2010. Different responses of denitrification rates and denitrifying bacterial communities to hydrologic pulsing in created wetlands. Soil Biology and Biochemistry. 42:1721-1727.

U.S. Army Corps of Engineers (USACE). 2005. Technical Standard for Water-table Monitoring of Potential Wetland Sites. ERDC TN-WRAP-05-2. Vicksburg, MS: U.S. Army Engineer Research and Development Center.

U.S. Army Corps of Engineers (USACE). 2010. Regional Supplement to the Corps of Engineers Wetland Delineation Manual: Atlantic and Gulf Coastal Plain Region (Version 2.0), ed. J. S. Wakeley, R. W. Lichvar, and C. V. Noble. ERDC/EL TR-10-20. Vicksburg, MS: U.S. Army Engineer Research and Development Center.

U.S. Army Corps of Engineers (USACE). 2013. Rivergaugues.com: Waterlevels of rivers and lakes (Rivergaugues.com; 25 September 2013).

U.S. Geological Survey (USGS). 2010. Establishing Marker Horizons. Patuxent Wildlife Research Center, Maryland, USA.

U.S. Department of Agriculture (USDA) - Natural Resources Conservation Service (NRCS). 2011. Field indicators of hydric soils in the United States, Version 7.0. ed. L. M. Vasilas, G. W. Hurt, and C. V. Noble. Washington, DC: USDA NRCS in cooperation with the National Technical Committee for Hydric Soils.

U.S. Department of Agriculture (USDA). 2013. The PLANTS Database (http://plants.usda.gov, 25 October 2013). National Plant Data Team, Greensboro, NC 27401-4901 USA. 
ERDC TN-EWN-14-4

August 2014

APPENDIX I:

\begin{tabular}{|c|c|c|c|}
\hline \multicolumn{4}{|c|}{ List of plant species observed during initial island survey, $27-28$ August 2013} \\
\hline Scientific Name & Common Name & Family & $\begin{array}{l}\text { Invasive } \\
\text { Status }\end{array}$ \\
\hline Sagittaria latifolia Willd. & broadleaf arrowhead & Alismataceae & $\mathrm{N}$ \\
\hline Alternantherea philoxeroides (Mart.) Griseb. & alligatorweed & Amaranthaceae & $\mathrm{I}$ \\
\hline Amaranthus australis (Gray) Sauer & southern amaranth & Amaranthaceae & $\mathrm{N}$ \\
\hline Cicuta maculata L. & spotted water hemlock & Apiaceae & $\mathrm{N}$ \\
\hline Hydrocotyle verticillata Thunb. & whorled marshpennywort & Apiaceae & $\mathrm{N}$ \\
\hline Colocasia esculenta (L.) Schott & coco yam & Araceae & $\mathrm{I}$ \\
\hline Pistia stratiotes L. & water lettuce & Araceae & $\mathrm{N}$ \\
\hline Baccharis halimifolia L. & eastern baccharis & Asteraceae & $\mathrm{N}$ \\
\hline Bidens laevis (L.) Britton, Sterns \& Poggenb. & smooth beggartick & Asteraceae & $\mathrm{N}$ \\
\hline Cirsium horridulum Michx. & yellow thistle & Asteraceae & $\mathrm{N}$ \\
\hline Eupatorium capillifollium (Lam.) Small & dogfennel & Asteraceae & $\mathrm{N}$ \\
\hline Euthamia spp. Nutt. Ex Cass. & goldentop & Asteraceae & $\mathrm{N}$ \\
\hline Iva annua L. & annual marsh elder & Asteraceae & $\mathrm{N}$ \\
\hline Lactuca spp. & lettuce & Asteraceae & - \\
\hline Mikania scandens (L.) Willd. & climbing hempvine & Asteraceae & $\mathrm{N}$ \\
\hline Pluchea rosea Godfrey & rosy camphorweed & Asteraceae & $\mathrm{N}$ \\
\hline Solidago altissima L. & Canada goldenrod & Asteraceae & $\mathrm{N}$ \\
\hline Solidago sempervirens L. & seaside goldenrod & Asteraceae & $\mathrm{N}$ \\
\hline Xanthium strumarium L. & rough cocklebur & Asteraceae & $\mathrm{N}$ \\
\hline Heliotropium indicum L. & Indian heliotrope & Boraginaceae & I \\
\hline Sambucus nigra L. ssp. canadensis & common elderberry & Caprifoliaceae & $\mathrm{N}$ \\
\hline Hypericum mutilum L. & dwarf St. Johnswort & Clusiaceae & $\mathrm{N}$ \\
\hline Commelina virginica L. & Virginia dayflower & Commelinaceae & $\mathrm{N}$ \\
\hline Ipomea spp. & morning-glory & Convolvulaceae & - \\
\hline Cornus foemina Mill. & stiff dogwood & Cornaceae & $\mathrm{N}$ \\
\hline Sicyos angulatus $\mathrm{L}$. & oneseed bur cucumber & Cucurbitaceae & $\mathrm{N}$ \\
\hline Cyperus esculentus L. & yellow nutsedge & Cyperaceae & I \\
\hline Cyperus pseudovegetus Steud. & marsh flatsedge & Cyperaceae & $\mathrm{N}$ \\
\hline Cyperus spp. & flatsedge & Cyperaceae & - \\
\hline Eleocharis spp. R. Br. & spikerush & Cyperaceae & - \\
\hline $\begin{array}{l}\text { Schoenoplectus americanus (Pers.) Volkart ex } \\
\text { Schinz \& R. Keller }\end{array}$ & chairmaker's bulrush & Cyperaceae & $\mathrm{N}$ \\
\hline Schoenoplectus californicus (C.A. Mey.) Palla & California bulrush & Cyperaceae & $\mathrm{N}$ \\
\hline Triadica sebifera (L.) Small & Chinese tallowtree & Euphorbiaceae & I \\
\hline Gleditsia aquatica Marsh. & water locust & Fabaceae & $\mathrm{N}$ \\
\hline Sesbania drummondii (Rydb.) Cory & poisonbean & Fabaceae & $\mathrm{N}$ \\
\hline Sesbania herbacea (Mill.) McVaugh & bigpod sesbania & Fabaceae & $\mathrm{N}$ \\
\hline Vigna luteola (Jacq.) Benth. & hairypod cowpea & Fabaceae & $\mathrm{N}$ \\
\hline Vigna unguiculata (L.) Walp. & cowpea & Fabaceae & - \\
\hline Hydrilla verticillata (L. f.) Royle & waterthyme & Hydrocharitaceae & I \\
\hline Iris virginica $\mathrm{L}$. & Virginia iris & Iridaceae & $\mathrm{N}$ \\
\hline Lemna minor L. & common duckweed & Lemnaceae & $\mathrm{N}$ \\
\hline Crinum americanum $\mathrm{L}$. & seven sisters & Liliaceae & $\mathrm{N}$ \\
\hline Lygodium japonicum (Thunb.) Sw. & Japanese climbing fern & Lygodiaceae & I \\
\hline Ammannia spp. & redstem & Lythraceae & $\mathrm{N}$ \\
\hline Lythrum alatum L. & winged lythrum & Lythraceae & $\mathrm{N}$ \\
\hline Lythrum lineare L. & wand lythrum & Lythraceae & $\mathrm{N}$ \\
\hline Hibiscus lasiocarpos Cav. & rosemallow & Malvaceae & $\mathrm{N}$ \\
\hline
\end{tabular}


ERDC TN-EWN-14-4

August 2014

\begin{tabular}{|c|c|c|c|}
\hline Kosteletzkya virginica (L.) C. Presl ex A. Gray & Virginia saltmarsh mallow & Malvaceae & $\mathrm{N}$ \\
\hline Morus rubra L. & red mulberry & Moraceae & $\mathrm{N}$ \\
\hline Morella cerifera (L.) Small & wax myrtle & Myricaceae & $\mathrm{N}$ \\
\hline Nelumbo lutea Willd. & American lotus & Nelumbonaceae & $\mathrm{N}$ \\
\hline Nymphaea odorata Aiton ssp. odorata & American white waterlily & Nymphaeaceae & $\mathrm{N}$ \\
\hline Ludwigia sp. & primrose-willow & Onagraceae & - \\
\hline Platanus occidentalis L. & American sycamore & Platanaceae & $\mathrm{N}$ \\
\hline Phragmites australis (Cav.) Trin. Ex Steud. & common reed & Poacaeae & $\mathrm{N}$ \\
\hline Echinochloa walteri (Pursh) A. Heller & coast cockspur grass & Poaceae & $\mathrm{N}$ \\
\hline Leersia oryzoides (L.) Sw. & rice cutgrass & Poaceae & $\mathrm{N}$ \\
\hline Panicum repens L. & torpedo grass & Poaceae & $\mathrm{I}$ \\
\hline Paspalum L. & crowngrass & Poaceae & - \\
\hline Polygonum hydropiperoides Michx. & swamp smartweed & Polygonaceae & $\mathrm{N}$ \\
\hline Polygonum punctatum Ell. & dotted smartweed & Polygonaceae & $\mathrm{N}$ \\
\hline Eichhornia crassipes (Mart.) Solms & common water hyacinth & Pontederiaceae & $\mathrm{I}$ \\
\hline Pontederia cordata L. & pickerelweed & Pontederiaceae & $\mathrm{N}$ \\
\hline $\begin{array}{l}\text { Samolus valerandi L. ssp. parviflorus (Raf.) } \\
\text { Hulten }\end{array}$ & seaside brookweed & Primulaceae & $\mathrm{N}$ \\
\hline Rubus argutus Link & sawtooth blackberry & Rosaceae & $\mathrm{N}$ \\
\hline Cephalanthus occidentalis L. & common buttonbush & Rubiaceae & $\mathrm{N}$ \\
\hline Galium spp. & bedstraw & Rubiaceae & - \\
\hline Ruppia maritima L. & widgeongrass & Ruppiaceae & $\mathrm{N}$ \\
\hline Salix nigra Marshall & black willow & Salicaceae & $\mathrm{N}$ \\
\hline Salvinia minima Baker & water spangles & Salviniaceae & $\mathrm{I}$ \\
\hline Saururus cernuus L. & lizard's tail & Saururaceae & $\mathrm{N}$ \\
\hline Solanum americanum Mill. & American black nightshade & Solanaceae & $\mathrm{N}$ \\
\hline Sphenoclea zeylanica Gaertn. & chickenspike & Sphenocleaceae & $\mathrm{I}$ \\
\hline Thelypteris kunthii (Desv.) Morton & Kunth's maiden fern & Thelypteridaceae & $\mathrm{N}$ \\
\hline Typha latifolia L. & broadleaf cattail & Typhaceae & $\mathrm{N}$ \\
\hline Boehmeria cylindrica (L.) Sw. & smallspike false nettle & Urticaceae & $\mathrm{N}$ \\
\hline Phyla lanceolata (Michx.) Greene & lanceleaf fogfruit & Verbenaceae & $\mathrm{N}$ \\
\hline Phyla nodiflora (L.) Greene & turkey tangle fogfruit & Verbenaceae & $\mathrm{N}$ \\
\hline Ampelopsis arborea (L.) Koehne & peppervine & Vitaceae & $\mathrm{N}$ \\
\hline Ampelopsis cordata Michx. & heartleaf peppervine & Vitaceae & $\mathrm{N}$ \\
\hline
\end{tabular}

